\title{
Türkçe Öğretmeni Adaylarının Dijital Yazmayla İle İlgili Görüşlerinin İncelenmesi $^{a}$
}

Mete Yusuf Ustabulut $t^{\mathrm{b}, \mathrm{c}}$,

\section{Özet}

Bu araştırmanın amacı Türkçe öğretmeni adaylarının dijital yazmayla ile ilgili görüşlerini belirlemektir. Araştırmada nicel araştırma modellerinden ilişkisel tarama modeli kullanılmıştır. Araştırmanın örneklem grubunu basit seçkisiz örnekeleme yöntemiyle seçilen 229 Türkçe öğretmeni adayı oluşturmaktadır. Araştırmada Dijital Ortamda Yazmaya İlişkin Tutum Ölçeği kullanılmıştır. Araştırmanın verileri normal dağılım gösterdiği için betimsel analiz, t-testi, ANOVA, koelasyon analizi yapılmıştır. Türkçe öğretmeni adayları günde 5 saatten fazla internet kullandıklarını belirtmişlerdir. Öğretmen adayları genel olarak dijital yazmayı kullandıklarını ve günlük 3 saatin üzerinden dijital yazdıklarını belirtmişlerdir. Araştırmaya katılanlar dijital yazmanın kolaylık sağladığını, dijital ortamda her türlü yazma işlemini kolaylıkla gerçekleştirebildiklerini dile getirmişlerdir. Türkçe öğretmeni adaylarının dijital yazmayla ile ilgili görüşleriyle cinsiyetleri, not ortalamaları, yazma şekilleri, yaşları, sınıf düzeyleri, internette geçirdikleri süre, dijital yazma süreleri arasında ilişki olduğu görülmüştür.
Anahtar Kelimeler

Dijital Yazma

Türkçe Öğretmeni Adayları

Yazma Becerisi

Makale Hakkında

Geliş Tarihi: 01.03.2021

Kabul Tarihi: 21.06.2021

Doi: 10.18026/cbayarsos.889022

\section{Analysis of the Opinions of Turkish Language Teachers About Digital Writing}

\begin{abstract}
The study aims to determine the views of Turkish language teacher candidates about digital writing. In the research, the relational screening model, one of the quantitative research models, was used. The sample group of the study consists of 229 Turkish language teacher candidates selected by a simple random sampling method. In the research, the Attitude Scale for Writing in Digital Media was used. Since the data of the study showed normal distribution, descriptive analysis, t-test, ANOVA and coelation analysis were performed. Turkish language teacher candidates declared that they use the internet more than 5 hours a day. Teacher candidates expressed that they use digital writing and write digitally for more than 3 hours daily. Participants in the study stated that digital writing provides convenience and that they can easily perform all kinds of writing operations in a digital environment. It was observed that there was a relationship between Turkish language teacher candidates' opinions on digital writing and their gender, grade point averages, writing styles, ages, grade levels, time spent on the internet, and digital writing time.
\end{abstract}

Keywords

Digital Writing

Turkish Language Teacher

Candidates

Writing Skill

\section{About Article}

Received: 01.03.2021

Accepted: 21.06.2021

Doi: 10.18026/cbayarsos. 889022

\footnotetext{
a Bu araştırmanın etik kurulu izni Bayburt Üniversitesi Etik Kurulu tarafından 15.02.2021 tarihi 02 nolu oturumda 2021/20 karar sayısıyla alınmıştır. b meteustabulut@bayburt.edu.tr.

c Dr. Öğr. Üyesi, Bayburt Üniversitesi, Eğitim Fakültesi, Türkçe Eğitimi Ana Bilim Dalı, meteustabulut@bayburt.edu.tr. ORCID ID:

https://orcid.org/0000-0002-8864-645X
} 


\section{Giriş}

“Son yüzyılın en büyük yeniliği ve buluşu internet, hayatın birçok alanında değişimine neden olmuştur. Hayatın bütün alanlarındaki bu değişim, yeni bir düzenin oluşmasını sağlamıştır. İnternet, toplumu sosyolojik ve psikolojik yönden de etkilemiştir. Bu etki felsefik bir bakış açısıyla açılanabilir." (Bulunmaz, 2017:40).

Günümüzdeki hızlı değişimle berbaer insanlar bilgiyi, mobil cihazlar, tabletler ve bilgisayarlardan öğrenmektedir. 2020 yılı Global Dijital Raporu'na göre, internet kullanan kişi sayısı 4.54 milyara çıkmıştır. Dünya geneline baktığımızda sosyal medya kullanan 3.80 milyar, cep telefonu kullanan kişi sayısı ise 5.19 milyardan fazladır. Her gün ortalama bir kullanıcı çevrimiçi olarak 6 saat 43 dakika internet kullanmaktadır (Fundalina, 2020).

TÜİK, (2020) “2020, Hane Halkı Bilişim Teknolojileri (BT) Kullanım Araştırması” raporuna göre; İnternet kullanım oran 2020 yılında 16-74 yaş grubundaki kişilerde \%79,0 oldu. Bu oran, bir önceki yıl \%75,3'tü. Hanelerin \%90,7'sinin evden İnternete erişim olanağına sahip olduğu gözlendi. Bu oran bir önceki yılda \%88,3 düzeyindeydi.

Bu kadar önemli bir buluş dil becerilerinin kullanımında da büyük bir değişim başlatmıştır. "Artık insanlar bilgi edinmek için basılı kaynaklar ile beraber dijital ortamlardaki elektronik kaynakları, istek, görüş ve önerilerini paylaşmak için de kalem ve kâğıt yerine ekran ve klavyeleri kullanmaktadır. Bu değişim dil kullananları daha farklı becerilerle donatırken dil öğretimi süreçlerinde de dijital ortamlarda okuma, dinleme ve konuşma, yazma eylemlerinin doğru ve etkili biçimde nasıl gerçekleşeceğine dair yenilikler öğrencilere sunulmaktadır (Maden vd., 2018)".

Öğrencilerin hem ulusal hem de uluslararası düzeyde ihtiyaç duyacakları yetkinlikler Yenilenen Türkçe Dersi Öğretim Programı'nda ortaya konmuştur. Bu yetkinlikleri hayat boyu kullanabilecek beceri ve davranışlara dönüştürebilmeleri için anadilde iletişim, yabancı dillerde iletişim, matematiksel yetkinlik ve bilim/teknolojide temel yetkinlikler, dijital yetkinlik, öğrenmeyi öğrenme, sosyal ve vatandaşlıkla ilgili yetkinlikler, inisiyatif alma ve girişimcilik, kültürel farkındalık ve ifade olmak üzere sekiz önemli yetkinlik belirlenmiştir. (MEB, 2019).

Ülkemizde bugün yazma eğitimi ilkokulda başlamaktadır. Öğrencilerin yazma araç gereçleri ise; kalem, defter, silgi ve kalem tıraştır. Ancak teknolojik gelişmeler klavye ve ekran gibi yeni yazma araçlarını da geliştirmiştir (Duran, 2013: 181).

Kalemle yazma, dik veya bitişik eğik yazı, güzel yazı, mürekkeple süslü yazma gibi konular eskilerde yazı yazma deyince ilk akla gelenlerdendir. Bilgisayar, ipad, cep telefonu vb. araçlarla yazma ise günümüzde kullanılmaktadır. Günümüz kişileri artık hareket kabiliyeti yüksek klavyelerde yazı yazmayı tercih etmektedir. Bu durum okullarda öğrenciler etrafında hızlı bir şekilde yayılmaktadır. Yazılması zor zahmetli yoğunlaşmayı gerektiren yazma yerine kolay ve çok yoğunlaştırma istemeyen araçlarla yazı yazma günümüzde ön plana çıkmıştır. Klavyede yazı yazmak, sadece tuşlara basma gibi basit bir hareket istemektedir (Güneş, 2016).

Yapılan araştırmalar incelendiğinde (Baker ve Lastrapes, 2019; Geçgel, Kana ve Eren, 2020; Ilomäki, Paavola, Kantosalo ve Lakkala, 2016; Kurudayığlu ve Soysal, 2020; Larraz ve Esteve, 2015) dijital yazmayla ilgili araştırmanın olmadığı görülmektedir. Bu araştırmada Türkçe öğretmeni adaylarının dijital yazmayla ilgili görüşleri incelenmiştir. 


\section{Yöntem}

\section{Araştırma Modeli}

Türkçe öğretmeni adaylarının dijital yazmayla ilgili görüşlerinin alındığı bu araştırmada, Türkçe öğretmeni adaylarının dijital yazmayla ilgili görüşleriyle değişkenler arasında ilişki olup olmadığını belirleyebilmek amacıyla ilişkisel tarama modeli kullanılmıştır. İlişkisel tarama modeli iki ya da daha fazla değişken arasındaki ilişkilerin incelendiği araştırmalarda kullanılır (Karasar, 2013).

\section{Evren ve Örneklem}

Araştırmanın örneklem grubunu basit seçkisiz örnekeleme yöntemiyle seçilen 229 Türkçe öğretmeni adayı oluşturmaktadır.

Tablo 1. Araştırmanın Örneklem Grubunun Cinsiyetleri

\begin{tabular}{ccc}
\hline Cinsiyet & $\mathrm{f}$ & $\%$ \\
\hline Kadın & 167 & 72,9 \\
Erkek & 62 & 27,1 \\
\hline
\end{tabular}

Tablo 1 incelendiğinde araştırmaya katılanların 167'si kadın, 62'si erkektir.

Tablo 2. Araştırmaya Katılanların Yaş Grupları

\begin{tabular}{ccc}
\hline Yaş & f & $\%$ \\
\hline $18-19$ & 32 & 14,0 \\
$20-21$ & 99 & 43,2 \\
$22-23$ & 66 & 28,8 \\
24 ve üzeri & 32 & 14,0
\end{tabular}

Tablo 2 incelendiğinde araştırmaya katılanların 32'si 18-19 yaş aralığında, 99'u 20-21 yaş aralığında, 66'sı 22-23 yaş aralığında, 32'si ise 24 ve yaş dilimindedir.

Tablo 3. Araştırmanın Katılanların Not Ortalamaları

\begin{tabular}{ccc}
\hline Not Ortalamaları & $\mathrm{f}$ & $\%$ \\
\hline $0-2.99$ & 51 & 22,3 \\
$3.00-4.00$ & 178 & 77,7 \\
\hline
\end{tabular}

Tablo 3'e göre araştırmaya katılanların 51'i 0-2.99, 178'si ise 3.00-4.00 arası not aralığındadır.

Tablo 4. Araştırmaya Katılanların Sınıf Düzeyleri

\begin{tabular}{ccc}
\hline Sinif & $\mathrm{f}$ & $\%$ \\
\hline 1. Sinif & 49 & 21,4 \\
2. Sinif & 32 & 14,0 \\
3. Sinif & 78 & 34,1 \\
4. Sinif & 70 & 30,6
\end{tabular}

Tablo 4'e göre araştırmaya katılanların 49'u 1. Sınıf, 32'si 2. Sınıf, 78'i 3. Sınıf, 70'i ise 4. sınıfta öğrenim görmektedir. 


\section{Veri Toplama Araçları}

Araştırmada Susar Kırmızı, Kapıkıran ve Akkaya (2021) tarafından geçerlik ve güvenirlik çalışmaları yapılan Dijital Ortamda Yazmaya İlişkin Tutum Ölçeği (DOYAT) kullanılmıştır. Ölçek üç alt faktör (kolaylık, güdülenme, etki) ve 25 maddeden oluşmaktadır. Ölçeğin yapı geçerliğini belirlemek amacıyla yapılan analizler sonucunda Kaiser-Meyer Olkin değeri .90, Bartlett's testinin $\left[\chi^{2}=11662.49, \mathrm{sd}=300 \mathrm{p}<.0001\right]$ ise anlamlı olduğu görülmüştür. Ölçekte toplam varnasın \%60' 1 açıklanmıştır. Ölçek için yapılan doğrulayıcı faktör analizi sonucu $\chi^{2}=$ $(272, \mathrm{~N}=1501)=1895.32 ; \mathrm{RMSEA}=.063 ; \mathrm{SRMR}=.052 ; \mathrm{CFI}=.94$ ve $\mathrm{NNFI}=.94$ ile kabul edilebilir uyum değerlerine ulaştı̆̆ı görülmüş̧ür.

\section{Verilerin Toplanması ve Analizi}

Araştırmanın veri analizine başlamadan önce ölçekte yer alan alt faktörlerin basıklık ve çarpıklık değerlerine bakılmıştır.

Tablo 5. Çarpıklık ve Basıklık Değerleri

\begin{tabular}{ccc}
\hline Boyutlar & Çarpıklık & Basıklık \\
\hline Kolaylık & $-1,359$ & 1,896 \\
Güdülenme &, 283 &,- 389 \\
Etki &,- 691 &, 205 \\
\hline
\end{tabular}

Tablo 6 incelendiğinde veriler normal dağılım gösterdiği için betimsel analiz, t-testi, ANOVA, koelasyon analizi yapılmıştır.

\section{Etik Kurul İzni}

Bu araştırmanın etik kurulu izni Bayburt Üniversitesi Etik Kurulu tarafından 15.02.2021 tarihi 02 nolu oturumda 2021/20 karar sayısıyla alınmıştır.

\section{Bulgular}

Araştırmanın bu bölümünde elde edilen veriler analiz edilmiştir.

Tablo 6. Araştırmanın Katılanların İnternette Geçirdikleri Süre

\begin{tabular}{cccc}
\hline İnternette Geçirilen Süre & $\mathrm{f}$ & $\%$ \\
\hline $0-2$ saat & 10 & 4,4 \\
$2-3$ saat & 25 & 10,9 \\
$3-4$ saat & 48 & 21,0 \\
$4-5$ saat & 58 & 25,3 \\
5 saatten fazla & 88 & 38,4 \\
\hline
\end{tabular}

Tablo 6'ya göre araştırmaya katılanların 10'u 0-2; 25'i 2-3; 48'i, 3-4; 58' i 4-5 saat; 88' i ise 5 saatten fazla günlük internette vakit geçirdiklerini belirtmişlerdir.

Tablo 7. Araştırmanın Katılanların Yazma İçin Kullandığı Yöntem

\begin{tabular}{ccc}
\hline İnternette Geçirilen Süre & $\mathrm{f}$ & $\%$ \\
\hline Kağit & 102 & 44,5 \\
Dijital & 127 & 55,5 \\
\hline
\end{tabular}


Tablo 7 incelendiğinde araştırmaya katılanların 102'si kağıda, 127'si ise dijital olarak yazı yazdıklarını belirtmişlerdir.

Tablo 8. Araştırmanın Katılanların Günlük Dijital Yazma Süreleri

\begin{tabular}{ccc}
\hline İnternette Geçirilen Süre & $\mathrm{f}$ & $\%$ \\
\hline 0-30 dakika & 10 & 4,4 \\
30 dakika-1 saat & 25 & 10,9 \\
1 -2 saat & 48 & 21,0 \\
$2-3$ saat & 58 & 25,3 \\
3 saat üzeri & 88 & 38,4 \\
\hline
\end{tabular}

Tablo 8 incelendiğinde araştırmaya katılan Türkçe öğretmeni adaylarının 10'u 0-30 dakika; 25'i 30 dakika-1 saat, 48' i 1-2 saat, 58' i 2-3 saat, 88'i ise 3 saat üzeri günlük dijital olarak yazdıklarını ifade etmektedirler.

Tablo 9. Ölçekte Yer Alan Kolaylık Faktörüne Ait Tanımlayıcı İstatistik Analizleri

\begin{tabular}{|c|c|c|}
\hline Maddeler & $\overline{\mathrm{x}}$ & ss \\
\hline Dijital ortamdaki yazıların yıpranma/yırtılma olasılığı bulunmamaktadır. & 4,70 & ,646 \\
\hline Dijital ortamda yazarken satır aralıklarını istediğim gibi ayarlarım. & 4,65 & 680 \\
\hline Dijital ortamda yazarken ekranın ışı̆̆ını istediğim gibi ayarlarım. & 4,59 & ,722 \\
\hline Dijital ortamda yazmak kâ̆ğıt israfını önlemektedir. & 4,55 & 839 \\
\hline $\begin{array}{l}\text { Dijital ortamda yazarken duyguları anlatan ifadeler (emoji, sembol vb.) ekleme } \\
\text { kolaylığı bulunmaktadır. }\end{array}$ & 4,51 & 792 \\
\hline Dijital ortamda yazı yazarken yazı stili ve büyüklüğünü isteğim gibi ayarlayabilirim. & 4,48 & 861 \\
\hline $\begin{array}{l}\text { Dijital ortamdaki yazılara programın özellikleri doğrultusunda estetik bir görünüm } \\
\text { kazandırabilirim. }\end{array}$ & 4,39 & ,860 \\
\hline Dijital ortamda yazarken başka kaynaklardan kolayca alıntı yaparım. & 4,39 & ,899 \\
\hline $\begin{array}{l}\text { Dijital ortamda yazılanları dijital ortamda paylaşmak -kâğıda yapılan yazmaya oranla- } \\
\text { daha kolaydır. }\end{array}$ & 4,38 & ,951 \\
\hline Dijital ortam on parmak yazanlar için büyük kolaylıktır. & 4,37 & ,941 \\
\hline Dijital yazmalarda programın özelliklerinden dolayı yanlışı kolayca düzeltebilirim. & 4,32 & ,903 \\
\hline Dijital ortamda yazarken çizimler (tablo, grafik vb.) daha kolay oluşturulmaktadır. & 4,22 & 1,068 \\
\hline Dijital ortamda hem iki el hem de tek el ile yazabilirim. & 4,11 & 1,023 \\
\hline
\end{tabular}

Tablo 9 incelendiğinde Türkçe öğretmeni adayları, dijital ortamdaki yazıların yıpranma/yırtılma olasılığı bulunmadığını; dijital ortamda yazarken satır aralıklarını, ekranın ışı̆̆ını, yazı stili ve büyüklügünü istedikleri gibi ayarladıklarını; dijital ortamda yazmanın kâğıt israfını önlediğini, dijital ortamda yazarken duyguları anlatan ifadeler (emoji, sembol vb.) ekleme kolaylığı bulunduğunu, dijital ortamdaki yazılara programın özellikleri doğrultusunda estetik bir görünüm kazandırabildiğini, dijital ortamda yazarken başka kaynaklardan kolayca alıntı yaptıklarını, dijital ortamda yazılanları dijital ortamda paylaşmanın daha kolay olduğunu, dijital ortamın on parmak yazanlar için büyük kolaylık olduğunu, dijital yazmalarda programın özelliklerinden dolayı yanlışı kolayca 
düzeltebildiklerini, dijital ortamda yazarken çizimlerin (tablo, grafik vb.) daha kolay oluşturulduğunu, dijital ortamda hem iki el hem de tek el ile yazabildiklerini belirtmişlerdir.

Tablo 10. Ölçekte Yer Alan Güdülenme Faktörüne Ait Tanımlayıcı İstatistik Analizleri

\begin{tabular}{lcc}
\hline \multicolumn{1}{c}{ Maddeler } & $\overline{\mathrm{x}}$ & $\mathrm{ss}$ \\
\hline Dijital ortamda yazmak özgüvenimi arttırır. & 3,17 & 1,166 \\
Dijital ortamda yazarken daha akıcı düşünürüm. & 3,13 & 1,339 \\
Dijital ortamda yazmak benim için büyük bir keyiftir. & 3,03 & 1,180 \\
Derste dijital ortamda not tutmaktan hoşlanırım. & 2,82 & 1,342 \\
Dijital ortamda yazarken yazmanın doyumunu daha fazla hissederim. & 2,47 & 1,299 \\
Dijital yazma yapmadığım gün kendimde eksiklik hissederim. & 2,06 & 1,229 \\
\hline
\end{tabular}

Tablo 10 incelendiğinde araştırmaya katılan Türkçe öğretmeni adayları dijital ortamda yazmanın özgüvenlerini artırdığı, Dijital ortamda yazarken daha akıcı düşünme, Dijital ortamda yazmanın kendileri için büyük bir keyif olması, derste dijital ortamda not tutmak konularında kararsızlık yaşadıkları görülmektedir. Türkçe öğretmeni adayları dijital ortamda yazarken yazmanın doyumunu daha fazla hissetmediklerini, dijital yazma yapmadıkları gün kendilerinde eksiklik hissettiklerini ifade etmişlerdir.

Tablo 11. Ölçekte Yer Alan Etki Faktörüne Ait Tanımlayıcı İstatistik Analizleri

\begin{tabular}{lcc}
\hline \multicolumn{1}{c}{ Maddeler } & $\overline{\mathrm{x}}$ & ss \\
\hline Dijital ortamda yazmak gözlerimi yorar. & 4,51 &, 792 \\
Dijital ortamda yazı yazmak beden duruşu ile ilgili sağlık sorunlarına yol açabilir. & 4,35 &, 914 \\
Dijital ortamda yazmada kâğıda dokunmanın hazzı alınmaz. & 4,31 &, 966 \\
Dijital ortamlarda yazmak radyasyondan etkilenmeye neden olur. & 4,20 & 1,010 \\
Dijital ortamda yazarken kendimi iyi hissederim. & 3,21 & 1,086 \\
Dijital yazma sürdürülebilir yazma alışkanlığı geliştirmede etkili olamaz. & 2,97 & 1,226 \\
\hline
\end{tabular}

Tablo 11 incelendiğinde Türkçe öğretmeni adayları dijital ortamda yazmanın gözlerini yorduğunu, beden duruşu ile ilgili sağlık sorunlarına yol açabildiğini, radyasyondan etkilenmeye neden olduğunu; dijital ortamda yazmada kâğıda dokunmanın hazzını alamadıklarını belirtmişlerdir. Türkçe öğretmeni adayları dijital ortamda dinlerken kendilerini iyi hissetme ve dijital yazmanın sürdürülebilir yazma alışkanlı̆̆ı geliştirmede etkili olamayacağ 1 konusunda kararsızdırlar.

Tablo 12. Dijital Yazma Ölçeğinde Yer Alan Maddelere İlişkin Cinsiyete Göre t-testi Sonuçları

\begin{tabular}{lccccccc}
\hline \multicolumn{1}{c}{ Madde } & Cinsiyet & $\mathrm{n}$ & Ortalama & $\mathrm{ss}$ & $\mathrm{t}$ & $\mathrm{df}$ & $\mathrm{p}$ \\
\hline $\begin{array}{l}\text { Dijital ortamdaki yazılara programın } \\
\text { Özellikleri doğrultusunda estetik bir }\end{array}$ & Kadın & 167 & 4,46 &, 804 & 2,025 & 227 &, 044 \\
görünüm kazandırabilirim. & Erkek & 62 & 4,20 &, 977 & 1,853 & & \\
$\begin{array}{l}\text { Dijital ortamda yazarken ekranın ışı̆̆ını } \\
\text { istediğim gibi ayarlarım. }\end{array}$ & Kadın & 167 & 4,66 &, 607 & 2,304 & 227 &, 022 \\
& Erkek & 62 & 4,41 &, 950 & 1,894 & &
\end{tabular}




\begin{tabular}{|c|c|c|c|c|c|c|c|}
\hline $\begin{array}{l}\text { Dijital ortamdaki yazıların } \\
\text { yıpranma/yırtılma olasılığı } \\
\text { bulunmamaktadır. }\end{array}$ & $\begin{array}{l}\text { Kadın } \\
\text { Erkek }\end{array}$ & 167 & $\begin{array}{l}4,77 \\
4,53\end{array}$ & ,511 & $\begin{array}{l}2,526 \\
1,985\end{array}$ & 227 & ,012 \\
\hline \multirow{2}{*}{$\begin{array}{l}\text { Dijital ortamda yazarken satır } \\
\text { aralıklarını istediğim gibi ayarlarım. }\end{array}$} & Kadın & 167 & 4,71 & 610 & 2,179 & \multirow[t]{2}{*}{227} & \multirow[t]{2}{*}{,030 } \\
\hline & Erkek & 62 & 4,50 & 824 & 1,902 & & \\
\hline \multirow{2}{*}{$\begin{array}{l}\text { Dijital ortamda yazarken başka } \\
\text { kaynaklardan kolayca alıntı yaparım }\end{array}$} & Kadın & 167 & 4,48 & 790 & 2,571 & \multirow[t]{2}{*}{227} & \multirow[t]{2}{*}{,011 } \\
\hline & Erkek & 62 & 4,14 & 1,113 & 2,205 & & \\
\hline \multirow{2}{*}{$\begin{array}{l}\text { Derste dijital ortamda not tutmaktan } \\
\text { hoşlanırım. }\end{array}$} & Kadın & 167 & 2,69 & 1,347 & $-2,444$ & \multirow[t]{2}{*}{227} & \multirow[t]{2}{*}{,015 } \\
\hline & Erkek & 62 & 3,17 & 1,274 & $-2,508$ & & \\
\hline \multirow{2}{*}{$\begin{array}{l}\text { Dijital ortamda yazarken yazmanın } \\
\text { doyumunu daha fazla hissederim. }\end{array}$} & Kadın & 167 & 2,33 & 1,239 & $-2,638$ & \multirow[t]{2}{*}{227} & \multirow[t]{2}{*}{ 009 } \\
\hline & Erkek & 62 & 2,83 & 1,393 & $-2,501$ & & \\
\hline \multirow{2}{*}{$\begin{array}{l}\text { Dijital ortamlarda yazmak } \\
\text { radyasyondan etkilenmeye neden olur. }\end{array}$} & Kadın & 167 & 4,30 & 942 & 2,601 & \multirow[t]{2}{*}{227} & \multirow[t]{2}{*}{ 010 } \\
\hline & Erkek & 62 & 3,91 & 1,135 & 2,390 & & \\
\hline \multirow{2}{*}{$\begin{array}{l}\text { Dijital ortamda yazmak gözlerimi } \\
\text { yorar. }\end{array}$} & Kadın & 167 & 4,59 & 736 & 2,795 & \multirow[t]{2}{*}{227} & \multirow[t]{2}{*}{,006 } \\
\hline & Erkek & 62 & 4,27 & 890 & 2,564 & & \\
\hline \multirow{2}{*}{$\begin{array}{l}\text { Dijital ortamda yazı yazmak beden } \\
\text { duruşu ile ilgili sağllk sorunlarına yol } \\
\text { açabilir. }\end{array}$} & Kadin & 167 & 4,44 & 833 & 2,332 & \multirow[t]{2}{*}{227} & \multirow[t]{2}{*}{021} \\
\hline & Erkek & 62 & 4,12 & 1,078 & 2,075 & & \\
\hline
\end{tabular}

Tablo 11 incelendiğinde araştırmaya katılan kadın Türkçe öğretmeni adayları erkek Türkçe öğretmeni adaylarına göre dijital ortamdaki yazılara programın özellikleri doğrultusunda estetik bir görünüm kazandırabileceklerini, dijital ortamda yazarken ekranın 1şığını, satır aralıklarını istedikleri gibi ayarlayabildiklerini; dijital ortamdaki yazıların yıpranma/yırtılma olasılığı bulunmadığını, dijital ortamda yazarken başka kaynaklardan kolayca alıntı yaptıklarını, dijital ortamlarda yazmanın radyasyondan etkilenmeye neden olduğunu, dijital ortamda yazmanın gözlerini yorduğunu, dijital ortamda yazı yazmanın beden duruşu ile ilgili sağlık sorunlarına yol açtığını belirtmişlerdir. Erkek öğretmen adayları kadın öğretmen adaylarına göre Derste dijital ortamda not tutmaktan hoşlandıklarını, dijital ortamda yazarken yazmanın doyumunu daha fazla hissettiklerini belirtmişlerdir.

Tablo 12. Dijital Yazma Ölçeğinde Yer Alan Maddelere İlişkin Not Ortalamasına Göre ttesti Sonuçları

\begin{tabular}{lccccccc}
\hline \multicolumn{1}{c}{ Boyut } & $\begin{array}{c}\text { Not } \\
\text { Oratalaması }\end{array}$ & $\mathrm{n}$ & Ortalama & $\mathrm{ss}$ & $\mathrm{t}$ & $\mathrm{df}$ & $\mathrm{p}$ \\
\hline $\begin{array}{l}\text { Derste dijital ortamda not tutmaktan } \\
\text { hoşlanırım. }\end{array}$ & $0-2.99$ & 51 & 3,27 & 1,342 & 2,749 & 227 &, 006 \\
& $3.00-4.00$ & 178 & 2,69 & 1,318 & 2,721 & & \\
$\begin{array}{l}\text { Dijital ortamda yazmak gözlerimi } \\
\text { yorar. }\end{array}$ & $0-2.99$ & 51 & 4,21 &, 965 & - & 227 &, 002 \\
& $3.00-4.00$ & 178 & 4,59 &, 716 & & & \\
\end{tabular}

Tablo 12 incelendiğinde not oratalaması 0-2.99 arası olan Türkçe öğretmeni adayları not oratalaması 3.00-4.00 arası olan Türkçe öğretmeni adaylarına göre derste dijital ortamda not tutmaktan hoşlandıklarını ifade etmektedirler. Not oratalaması 3.00-4.00 arası olan Türkçe 
öğretmeni adayları not oratalaması 0-2.99 arası olan Türkçe öğretmeni adaylarına göre dijital ortamda yazmanın gözlerini yorduğunu dile getirmektedirler.

Tablo 13. Dijital Yazma Ölçeğinde Yer Alan Maddelere İlişkin Yazma Şekline Göre ttesti Sonuçları

\begin{tabular}{rccccccc}
\hline Boyut & Yazma Şekli & $\mathrm{n}$ & Ortalama & $\mathrm{ss}$ & $\mathrm{t}$ & $\mathrm{df}$ & $\mathrm{p}$ \\
\hline \multirow{2}{*}{ Kolaylık } & Kağıt & 102 & 4,2949 &, 61349 & $-3,691$ & 227 &, 000 \\
& Dijital & 127 & 4,5591 &, 46935 & & & \\
Güdüleme & Kağıt & 102 & 2,4820 &, 96840 & $-4,341$ & 227 &, 000 \\
& Dijital & 127 & 3,0276 &, 92624 & & & \\
Etki & Kağıt & 102 & 3,9314 &, 58226 & \multirow{2}{*}{, 045} & 227 &, 964 \\
& Dijital & 127 & 3,9278 &, 59894 & & & \\
\hline
\end{tabular}

Tablo 13 incelendiğinde araştırmaya katılan Türkçe öğretmeni adaylarından daha çok dijital yazmayı kullandığını belirtenler, daha çok kâğıdı kullandığını belirtenlere göre dijital ortamda yazmanın büyük kolaylık olduğunu, dijital ortamda yazmanın motivasyonlarını artırdığını belirtmişlerdir.

Tablo 14. Türkçe Öğretmeni Adaylarının Yaşları ile Dijital Yazma Ölçeği Maddeleri Arasındaki ANOVA Sonuçları

\begin{tabular}{cccccc}
\hline Madde & Varyansın Kaynağı & sd & F & p & Anlamlı Farklılık \\
\hline $\begin{array}{c}\text { Dijital ortamda } \\
\text { yazarken başka } \\
\text { kaynaklardan } \\
\text { kolayca alıntı } \\
\text { yaparım }\end{array}$ & Gruplar arası & 3 & 2,423 &, 047 & \\
$\begin{array}{c}\text { Dijital yazma } \\
\text { yapmadığım gün }\end{array}$ & Toplam & 225 & & & C-D \\
kendimde eksiklik & Gruplar arası & 3 & 3,754 &, 012 & \\
hissederim. & Toplam & 228 & & & C-B \\
\hline
\end{tabular}

$A=18-19 ; B=20-21 ; C=22-23 ; D=24$ ve üzeri

Tablo 14 incelendiğinde 22-23 yaş aralığındaki Türkçe öğretmeni adaylarının, 20-21 yaş aralığ ile 24 ve üzeri yaşındaki Türkçe öğretmeni adaylarına dijital ortamda yazarken başka kaynaklardan kolayca alıntı yaptıklarını, dijital yazma yapmadıkları gün kendimde eksiklik hissettiklerini ifade etmişlerdir.

Tablo 15. Türkçe Öğretmeni Adaylarının Sınıf Düzeyleriyle ile Dijital Yazma Ölçeğinde Yer Alan Maddeler Arasındaki ANOVA Sonuçları

\begin{tabular}{lcccccc}
\hline Madde & $\begin{array}{c}\text { Varyansın } \\
\text { Kaynağı }\end{array}$ & sd & F & p & $\begin{array}{c}\text { Anlamlı } \\
\text { Farklılık }\end{array}$ \\
\hline & Gruplar arası & 3 & 4,380 &, 005 & \\
$\begin{array}{l}\text { Dijital ortamda yazı yazarken yazı stili ve } \\
\text { büyüklügünü isteğim gibi ayarlayabilirim. }\end{array}$ & Gruplar içi & 225 & & & C-A \\
& Toplam & 228 & & &
\end{tabular}


Dijital ortamda yazarken satır aralıklarını istediğim gibi ayarlarım.

Dijital yazma sürdürülebilir yazma alışkanlığı geliştirmede etkili olamaz.

$\begin{array}{ccccc}\text { Gruplar arası } & 3 & 2,607 & , 053 & \\ \text { Gruplar içi } & 225 & & & \text { C-A } \\ \text { Toplam } & 228 & & & \\ \text { Gruplar arası } & 3 & 3,312 & , 021 & \\ \text { Gruplar içi } & 225 & & & \text { D-B } \\ \text { Toplam } & 228 & & & \end{array}$

$A=1 ; B=2 ; C=3 ; D=4$

Tablo 15 incelendiğinde 3. Sınıf Türkçe öğretmeni adayları, 1. Sınıf Türkçe öğretmeni adaylarına göre dijital ortamda yazı yazarken yazı stili ve büyüklüğünü, satır aralıklarını istekleri gibi ayarlayabildiklerini ifade etmektedirler. 4. Sınıf Türkçe öğretmeni adayları, 2. Sınıf Türkçe öğretmeni adaylarına göre dijital yazma sürdürülebilir yazma alışkanlığı geliştirmede etkili olamayacağını dile getirmektedir.

Tablo 16. Türkçe Öğretmeni Adaylarının İnternette Geçirdikleri Süreyle Dijital Yazma Ölçeği Boyutları Arasındaki ANOVA Sonuçları

\begin{tabular}{|c|c|c|c|c|c|}
\hline Madde & $\begin{array}{l}\text { Varyansın } \\
\text { Kaynağı }\end{array}$ & sd & $\mathrm{F}$ & $\mathrm{p}$ & $\begin{array}{l}\text { Anlamlı } \\
\text { Farklılık }\end{array}$ \\
\hline \multirow{3}{*}{$\begin{array}{l}\text { Dijital ortamda yazı yazarken yazı stili ve } \\
\text { büyüklüğ̈ünü isteğim gibi ayarlayabilirim. }\end{array}$} & Gruplar arası & 4 & 3,556 & ,008 & \multirow{3}{*}{$\mathrm{D}-\mathrm{C}$} \\
\hline & Gruplar içi & 224 & & & \\
\hline & Toplam & 228 & & & \\
\hline \multirow{3}{*}{$\begin{array}{l}\text { Dijital ortamdaki yazılara programın özellikleri } \\
\text { doğrultusunda estetik bir görünüm } \\
\text { kazandırabilirim. }\end{array}$} & Gruplar arası & 4 & 3,469 & ,009 & \multirow{3}{*}{$\mathrm{D}-\mathrm{C}$} \\
\hline & Gruplar içi & 224 & & & \\
\hline & Toplam & 228 & & & \\
\hline \multirow{3}{*}{$\begin{array}{l}\text { Dijital ortamda yazarken ekranın ışığını istediğim } \\
\text { gibi ayarlarım. }\end{array}$} & Gruplar arası & 4 & 4,800 & ,001 & \multirow{3}{*}{$\mathrm{D}-\mathrm{C}$} \\
\hline & Gruplar içi & 224 & & & \\
\hline & Toplam & 228 & & & \\
\hline \multirow{3}{*}{$\begin{array}{l}\text { Dijital ortamda yazarken satır aralıklarını } \\
\text { istediğim gibi ayarlarım. }\end{array}$} & Gruplar arası & 4 & 2,305 & ,059 & \multirow{3}{*}{ D-B } \\
\hline & Gruplar içi & 224 & & & \\
\hline & Toplam & 228 & & & \\
\hline \multirow{3}{*}{$\begin{array}{l}\text { Dijital ortamda yazarken başka kaynaklardan } \\
\text { kolayca alıntı yaparım }\end{array}$} & Gruplar arası & 4 & 4,582 & ,001 & \multirow{3}{*}{$\mathrm{D}-\mathrm{C}$} \\
\hline & Gruplar içi & 224 & & & \\
\hline & Toplam & 228 & & & \\
\hline
\end{tabular}

$A=0-2 ; B=2-3 ; C=3-4 ; D=4$ ve üzeri

Tablo 16 incelendiğinde 4 ve üzeri saat internette vakit geçiren Türkçe öğretmeni adayları, 34 saat arası internette vakit geçiren öğretmen adaylarına göre dijital ortamda yazı yazarken yazı stili ve büyüklüğünü, ekran ışığını, istekleri gibi ayarlayabildiklerini; dijital ortamdaki yazılara programın özellikleri doğrultusunda estetik bir görünüm kazandırabildiklerini, dijital ortamda yazarken başka kaynaklardan kolayca alıntı yaptıklarını belirtmektedirler. 4 ve üzeri saat internette vakit geçiren Türkçe öğretmeni adayları, 2-3 saat arası internette vakit 
geçiren öğretmen adaylarına göre dijital ortamda yazarken satır aralıklarını istediğim gibi ayarladıklarını ifade etmektedirler.

Tablo 17. Türkçe Öğretmeni Adaylarının Günlük Dijital Yazma Süreleriyle Dijital Yazma Ölçeği Boyutları Arasındaki ANOVA Sonuçları

\begin{tabular}{|c|c|c|c|c|c|}
\hline Madde & $\begin{array}{l}\text { Varyansın } \\
\text { Kaynağ }\end{array}$ & sd & $\mathrm{F}$ & $\mathrm{p}$ & $\begin{array}{l}\text { Anlamli } \\
\text { Farklılık }\end{array}$ \\
\hline \multirow{3}{*}{$\begin{array}{l}\text { Dijital ortam on parmak yazanlar için büyük } \\
\text { kolaylıktır. }\end{array}$} & Gruplar arası & 4 & 3,556 & , 008 & \multirow{3}{*}{ C-A } \\
\hline & Gruplar içi & 224 & & & \\
\hline & Toplam & 228 & & & \\
\hline \multirow{3}{*}{$\begin{array}{l}\text { Dijital yazma yapmadı̆̆ım gün kendimde } \\
\text { eksiklik hissederim. }\end{array}$} & Gruplar arası & 4 & 3,469 & ,009 & \multirow{3}{*}{$\begin{array}{l}\text { E-A } \\
\text { E-B }\end{array}$} \\
\hline & Gruplar içi & 224 & & & \\
\hline & Toplam & 228 & & & \\
\hline \multirow{3}{*}{$\begin{array}{l}\text { Dijital ortamda yazmak benim için büyük bir } \\
\text { keyiftir. }\end{array}$} & Gruplar arası & 4 & 4,800 & 001 & \multirow{3}{*}{ E-A } \\
\hline & Gruplar içi & 224 & & & \\
\hline & Toplam & 228 & & & \\
\hline \multirow{3}{*}{ Dijital ortamda yazmak özgüvenimi arttırır. } & Gruplar arası & 4 & 2,305 & 059 & \multirow{3}{*}{ E-A } \\
\hline & Gruplar içi & 224 & & & \\
\hline & Toplam & 228 & & & \\
\hline \multirow{3}{*}{$\begin{array}{c}\text { Dijital ortamda yazarken kendimi iyi } \\
\text { hissederim. }\end{array}$} & Gruplar arası & 4 & 4,582 & ,001 & \multirow{3}{*}{ E-A } \\
\hline & Gruplar içi & 224 & & & \\
\hline & Toplam & 228 & & & \\
\hline
\end{tabular}

$A=0-30$ dakika; $B=30$ dakika-1 saat; $C=1-2$ saat; $D=2-3$ saat; $E=3$ saat ve üzeri

Tablo 17 incelendiğinde günlük 3 saat ve üzeri dijital yazdıklarını ifade eden Türkçe öğretmeni adayları, 0-30 dakika arası dijital yazdıklarını ifade eden öğretmen adaylarına göre dijital ortamda yazmanın kendileri için büyük bir keyif olduğunu, dijital ortamda yazmanın özgüvenlerini arttırdığını, dijital ortamda yazarken kendimi iyi hissettiklerini ifade etmektedirler. Günlük 3 saat ve üzeri dijital yazdıklarını ifade eden Türkçe öğretmeni adayları, 0-1 saat arası dijital yazdıklarını ifade eden öğretmen adaylarına göre dijital yazma yapmadkları gün kendilerini eksiklik hissetmekte dile getirmişlerdir. günlük 1-2 saat arası dijital yazdıklarını ifade eden Türkçe öğretmeni adayları, 0-30 dakika arası dijital yazdıklarını ifade eden öğretmen adaylarına göre dijital ortamın on parmak yazanlar için büyük kolaylık olduğunu belirtmişlerdir.

\section{Tartışma, Sonuç ve Öneriler}

21. yüzyılda teknolojinin ilerlemesiyle beraber dijital ortamda dört temel dil becerisinin kullanımı artmıştır. Salgın sürecinde dijital kullanımın daha da artmasıyla bu alanda yapılan araştırmalar da artmıştır (De Roock, 2020; Dahlström, 2019; Gonzales, 2018; Yamaç, Öztürk ve Mutlu, 2020). Bu araştırmada öncelikle Türkçe öğretmeni adaylarının dijital yazmayı kullanma süreleri üzerinde durulmuştur. Türkçe öğretmeni adayları günde 5 saatten fazla internet kullandıklarını belirtmişlerdir. Öğretmen adayları genel olarak dijital yazmayı kullandıklarını 
ve günlük 3 saatin üzerinden dijital yazdıklarını belirtmişlerdir. Araştırmaya katılanlar dijital yazmanın kolaylık sağladığını, dijital ortamda her türlü yazma işlemini kolaylıkla gerçekleştirebildiklerini dile getirmişlerdir. Bunun yanısıra dijital yazmanın kendilerini güdülediğini, dijital ortamda yazmanın özgüvenlerini artırdığını, kendilerine büyük bir keyif verdiğini, dijital yazamadıkları zaman kendilerinde büyük bir eksiklik hissettiklerini ifade etmişlerdir. Türkçe öğretmeni adayları dijital yazmanın sağlık problemlerine yol açabileceğini, beden duurşu ile ilgili problem olabileceğini düşünmektedirler. Öğretmen adayları dijital yazmanın sürdürülebilir yazma alışkanlığını geliştirmede etkili olabileceğini belirtmektedirler. Türkçe öğretmeni adaylarının dijital yazmayla ile ilgili görüşleriyle cinsiyetleri, not ortalamaları, yazma şekilleri, yaşları, sınıf düzeyleri, internette geçirdikleri süre, dijital yazma süreleri arasında ilişki olduğu görülmüştür. Kadın öğretmen adayları, dijital yazmanın estetik ve sağlık konusunda görüşleri konusunda erkek öğretmen adaylarından ayrılmışlardır. Erkek öğretmen adaylarının dijital not tutma konusunda istekli oldukları görülmüştür. Dijiyal yazmayı kullananlar öğretmen adayları, dijital yazmanın kolay ve motivasyonlarını arttırdığını, sağlık sorunları yaratmasının çok önemli olmadığını dile getirmişlerdir. 4. sınıf Türkçe öğretmeni adayları, 2. sınıf Türkçe öğretmeni adaylarına göre dijital yazma sürdürülebilir yazma alışkanlığı geliştirmede etkili olamayacağını belirtmişlerdir. İnternette uzun süre vakit geçiren öğretmen adayları yazı stili ve büyüklüğünü, ekran ışığı, satır aralığı ve alıntı yapma konularını önemsediklerini belirtmişlerdir. Dijital ortamlarda günlük 3 saatin üzerinde yazı yazanlar dijital yazmanın kendileri için çok önemli olduğunu, kendilerine çok keyif verdiğini, özgüvenlerini arttırıp kendilerine büyük keyif verdiğini ifade etmişlerdir.

\section{Kaynakça}

Baker, S. F., \& Lastrapes, R. E. (2019). The writing performance of elementary students using a digital writing application. Interactive Technology and Smart Education, 16(4), 343-362. https://doi.org/10.1108/ITSE-08-2018-0057

Bulunmaz, B. (2017). Yeni medya okuryazarlığ1 ve haberde doğruluk alg1sı. Journal of Research in Education and Teaching-Jret , 6(3), 38-50.

Dahlström, H. (2019). Digital writing tools from the student perspective. Education and Information Technologies, 24(2), 1563-1581.

De Roock, R. S. (2020). On the Material Consequences of (Digital) Literacy: Digital writing with, for, and against racial capitalism. Theory Into Practice. https://www.tandfonline.com/doi/full/10.1080/00405841.2020.1857128

Duran, E. (2013). Yazmada etkililik: Kalem ve klavyeye yönelik bir karşılaştırma. Turkish Studies, 8(3), 179-187.

Fundalina, (2020). 2020 Yilı Global Dijital Raporu. Erşim Adresi: https://www.fundalina.com/2020-yili-global-dijital-raporu/ Erişim Tarihi: 20.01.2021

Geçgel, H., Kana, F.,\& Eren, D . (2020). Türkçe eğitiminde dijital yetkinlik kavramının farklı değişkenler açısından incelenmesi. Ana Dili Eğitimi Dergisi, 8 (3) , 886-904. DOI: 10.16916/aded.742352 
Gonzales, L. (2018). Sites of translation: What multilinguals can teach us about digital writing and rhetoric (p. 153). University of Michigan Press.

Güneş, F. (2016). Eğitimde kalem ve tuşlarla yazma tartışmaları. Bartın Üniversitesi Ĕ̆gitim Fakültesi Dergisi 5(1), 19-33.

Ilomäki, L., Paavola, S., Kantosalo, A. and Lakkala, M. (2016). Digital Competence-an emergent boundary concept for policy and educational research. Educ. Inf. Technol (21), 655-679.

Karasar, N. (2013). Bilimsel araştırma yöntemi (25. Basım). Ankara: Nobel Yayın Dağıtım.

Kurudayığlu, M. ve Soysal, T. (2020). 2018 Türkçe dersi öğretim programı'nın dijital yetkinlik bakımından incelenmesi. Mehmet Akif Ersoy Üniversitesi Ĕ̆itim Fakültesi Dergisi, 12(54), 184199.

Larraz, V. and Esteve, F. (2015). Evaluating digital competence in simulation environments. E. G. Bullen, In Teaching and learning in digital worlds, strategies and issues in higher education (s. 99-105). Tarragone: URV.

Maden, S., Banaz, E., Maden, A. (2018). Türkçe öğretmeni adaylarının dijital ortamlardaki yazma alışkanlıkları. Eğitim ve Öğretim Araştırmaları Dergisi, 7 (1), 103-112.

MEB, (2019). Türkçe dersi öğretim programı (İlkokul ve Ortaokul 1, 2, 3, 4, 5, 6, 7 ve 8. Sinıflar). Ankara: Milli Eğitim Bakanlığ1. https://mufredat.meb.gov.tr/Dosyalar/20195716392253-02T\%C3\%BCrk\%C3\%A7e\%20\%C3\%96\%C4\%9Fretim\%20Program $\%$ C4\%B1\%202019.pdf Erişim Tarihi: 15.01.2021

Susar Kırmızı, F., Kapıkıran, Ş. ve Akkaya, N. (2021). Dijital ortamda yazmaya ilişkin tutum ölçeği (DOYAT): Ölçek geliştirme çalışması. Pamukkale Üniversitesi Ĕ̆itim Fakültesi Dergisi, 25(52), 1-28.

TÜIK, (2020). 2020 Hane halkı Bilişim Teknolojileri (BT) Kullanım Araştırması. https://data.tuik.gov.tr/Bulten/Index?p=Hanehalki-Bilisim-Teknolojileri-(BT)-KullanimArastirmasi-2020-33679. Erişim Tarihi: 09.01.2021

Yamaç, A., Öztürk, E., \& Mutlu, N. (2020). Effect of digital writing instruction with tablets on primary school students' writing performance and writing knowledge. Computers $\mathcal{E}$ Education, 157, 1-18, https://doi.org/10.1016/j.compedu.2020.103981 